DOI 10.37882/2223-2982.2021.09.34

\title{
КОНФЛИКТОГЕННЫЙ ПОТЕНЦИАЛ ИМЕН СОБСТВЕННЫХ (НА МАТЕРИАЛЕ ИНТЕРНЕТ-КОММЕНТАРИЕВ К ПОЛИТИЧЕСКИМ НОВОСТЯМ НА САЙТАХ КР.RU И VARLAMOV.RU) ${ }^{1}$
}

\section{THE CONFLICTOGENIC POTENTIAL OF PROPER NAMES (BASED ON THE MATERIAL OF INTERNET COMMENTS ON POLITICAL NEWS ON WEBSITES KP.RU AND VARLAMOV.RU)}

I. Falomkina

Summary: The article analyzes the word-formation, lexical, spelling, phonetic, graphic ways of transforming proper names in the Internet space. The actual material of the study is comments on political news on websites kp.ru and varlamov.ru, including distorted forms of toponyms. The following research methods are used in the work: the descriptive method, including observation, generalization, classification, the method of linguistic analysis of language material, the method of random sampling.

The author notes the predominance of phonetic and word-forming methods of transformation of toponyms. The phonetic language game consists in fixing the features of oral communication that are impossible in written speech. When transforming toponyms, the following techniques are used: imitation of the speech of a native speaker of a foreign language, territorial dialect, vernacular, playing transliteration. Word-formation language game involves rethinking the word-formation structure of a word, contamination (addition of a toponym and a word with negative-evaluative semantics), games with abbreviations, creating new words using suffixation or prefix, truncation of proper names. The author believes that distorted toponyms become one of the factors of the unfolding of the conflict scenario of communication.

Keywords: language game, distortion of proper names, conflict, trolling, Internet comment.
$\mathrm{T}$ ехника обыгрывания имен собственных имеет давнюю историю, что, безусловно, не могло не остаться вне фокуса внимания лингвистов. Языковая игра «нередко основывается на ониме с его звукографической оболочкой, ассоциативным объемом, семантико-прагматическим и словообразовательным потенциалами» $[1$, с. 66]. Предметом исследования становятся ономастические игры в текстах фольклорных жаров [2],
Фаломкина Ирина Павловна

К.филол.н., доцент, Кемеровский государственный университет

falomkina@mail.ru

Аннотация: В статье анализируются словообразовательные, лексические, орфографические, фонетические, графические способы трансформации имен собственных в интернет-пространстве. Фактическим материалом исследования являются комментарии к политическим новостям на сайтах kp.ru и varlamov.ru, включающие искаженные формы топонимов.

В работе применяются описательный метод исследования, включающий наблюдение, обобщение, классификацию, метод лингвистического анализа языкового материала, метод случайной выборки.

Автор отмечает преобладание фонетических и словообразовательных приемов трансформации топонимов. Фонетическая языковая игра заключается в фиксации особенностей устной коммуникации, невозможных в письменной речи. При трансформации топонимов используются следующие приемы: имитация речи носителя иностранного языка, территориального диалекта, просторечия, обыгрывание транслитерации. Словообразовательная языковая игра предполагает переосмысление словообразовательной структуры слова, контаминацию (сложение топонима и слова с негативно-оценочной семантикой), игры с аббревиатурами, создание новых слов с помощью суффиксации или префиксации, усечение имен собственных.

Автор полагает, что искаженные топонимы становятся одним из факторов разворачивания конфликтного сценария коммуникации.

Ключевые слова: языковая игра, искажение имен собственных, конфликт, троллинг, интернет-комментарий.

литературно-фольклорных произведениях, в художественных текстах [3,4].

В настоящее время языковые игры с онимами стали неотъемлемой частью языка СМИ и обыденной интернет-коммуникации [5,6]. А.В. Зубарева обращает внимание на активное функционирование искаженных вариантов имен политиков, которые в результате языковой

Исследование выполнено при финансовой поддержке РФФИ в рамках научного проекта № 20-412-420004 р_а 
игры, приобретают пейоративную или даже оскорбительную окраску. Автор также отмечает, что в игру могут вовлекаться и географические названия [7]. Можно отметить ряд работ, направленных на изучение функционирующих в интернет-пространстве имен собственных через призму языковой игры. Так, Е.В. Каллистратидис анализирует некоторые особенности словообразования и употребления игровых трансформов (антропонимов и топонимов), уделяя внимание регулярности употребления этих единиц в интернет-текстах. Автор делает вывод о том, что «целый ряд единиц с мощным инвективным потенциалом, появившихся в результате лавинообразного словотворчества, становится неотъемлемой частью повседневных речевых практик рядовых граждан, интересующихся социально-политическими вопросами» $[8, с .158]$.

Ономастические игры в интернет-контексте исследует Б.Я. Шариффулин, описывая игровые трансформации имен и фамилий американских и украинских политиков, а также игры с топонимами Украина и Россия [9].

Материалом нашего исследования стали интернеткомментарии к политическим новостям в интернет-издании KP.RU и в блоге varlamov.ru, который можно охарактеризовать как авторское СМИ. Исследователи отмечают, что комментарии к политическим новостям часто разворачиваются по конфликтному сценарию, текст новости же является лишь стимулом для выражения собственных политических взглядов [10, с. 163]. Мы полагаем, что одним из факторов, провоцирующих разворачивание конфликтного сценария, является употребление искаженных имен собственных. Имя собственное условно, но его звуковая оболочка и внутренняя форма становятся базой для актуализации определенного смысла, часто негативного. М. Плотникова, анализируя языковую игру как средство инвективы, отмечает, что в конфликтном дискурсе «выбор средств воплощения игрового кода обусловлен интенцией «уколоть», обидеть адресата, поэтому игровой приём должен быть легко считываемым, не характеризоваться многослойностью и сложностью интерпретации» [11].

Цель работы - описание приемов искажения имен собственных (графических, фонетических, словообразовательных, лексических), детерминирующих эскалацию коммуникативного конфликта.

Словообразовательная языковая игра предполагает переосмысление словообразовательной структуры слова, контаминацию, образование дериватов из словосочетаний, аббревиацию, создание новых слов с помощью суффиксации или префиксации. Наиболее продуктивным способом языковой игры в сфере топонимов является контаминация слов, в частности, наложение, при котором у окказионального топонима оказывается общая для исходных слов часть. При этом чаще всего происходит формальное видоизменение (усечение) исходных слов в составе новообразования. При контаминации могут скрещиваться два имени собственных либо имя собственное с именем нарицательным.

Сатана из Фашингтона стравливает дураков наивных [https://www.kp.ru/daily/28298/4437825/]. Топоним - результат комбинации слов фашизм и Вашингтон.

И н...я им Домбабве и Луганда, если дома то же самое [https://varlamov/ru/14176965.html]. Теперь понятно на сколько отстала Укруанда... [https://www.kp.ru/ daily/28305.5/4445508/]. Произошла контаминация топонимов с названиями африканских стран: Домбасс + 3имбабве, Луганск + Уганда, Украина + Руанда.

Ялтантида выглядит как Атлантида [https://varlamov/ru/14176965.html].

Встречаются игровые варианты, основанные на контаминации топонима и нецензурного слова.

Задумайтесь! Рашка вернет Украине ГЕРОЕВ, а мы в Педерацию вышвырнем отбросы... [https://varlamov/ ru/3950411.html].

Наконец то он сможет посидеть в окопах Донбабве и Лугандона. Его уже там заждались [https://varlamov/ ru/3795237.html].

Словообразовательная игра может строиться на комбинации усеченного имени собственного и имени нарицательного или глагола (с усечением и без), созвучных исходному топониму, чаще с негативно-оценочной семантикой/ грязия и укради на замечательный союз у memu Hambl

Зато по запасам соломы и кизяка уркаина занимаem первое место в мире! После Зимбабве! [https://www. kp.ru/daily/27288/4425814/].

Нидергланды и им подобные поймут, только когда uх nотопят. Bот тогда розарутся, что их обидела Россия. По хорошему они не понимают - это западная дерьмократия [https://www.kp.ru/daily/28298.4/4436898/].

Уних в Даунбассе денег просто завались, вот и шлют куда попало [https://www.kp.ru/daily/27257/4389540/].

Лиха беда - начало. Кого в стране славят - тем и называются. Будет в укрорейхе еще и гитлерюгенд, и батальон СС «Галичина» [https://www.kp.ru/ daily/28307/4447906/]

Топоним Крымль [https://varlamov/ru/3615060.html] представляет собой соединение двух созвучных имен 
собственных.

Трансформация топонима может быть связана с добавлением к исходному слову суффиксов и суффиксоидов -бад, -ляндия, -лэнд: Уже привыкли к сказкам про лапшу. Плавно переходим на Украину, в Масквабаде всё спокойно [https://www.kp.ru/online/news/4361776/]. В слове содержится намек на миграционную ситуацию в столице.

В отдельных случаях от исходного топонима может сохраниться одна буква: да больше некуда поехать погулять. Везде был, а в Дерляндии нет. А после Дерляндии можно и на покой Нерою [https://www.kp.ru/ daily/28305.5/4445222/]. Так как интернет-комментарий вторичен по отношению к исходному тексту, читателю не составляет труда понять, о каком географическом объекте идет речь: политическая новость была посвящена ситуации на Донбассе.

В следующем комментарии игровой топоним образован по аналогии с городами Рязань, Сызрань и т.д.: в Американь за гонораром....? [https://www.kp.ru/ daily/28305.5/4445990/].

Одним из способов искажения имени собственного может быть его усечение: Укра токсична для Нато. Но полезна как разменный фонд и ресурс который не жалко. Втопкуукру [https://www.kp.ru/daily/27264/4397588/]. Усечение топонима может сопровождаться экспрессивной аффиксацией:

я, вообще, люблю писать Юкрайна. Интересно звучит. Уменьшительно-ласкательно: Украшка [https:// varlamov/ru/4286078.html].

Весьма разнообразны в интернет-пространстве варианты языковой игры с аббревиатурами. По отношению к США часто используется прием дезаббревиации: как впрочем и все остальные (включая Зелю) - не решают..., ибо все без исключения решения принимаются в Госдеnе Слипшихся Штатов... [https://www.kp.ru/ daily/28305.5/4445508/].

Аббревиатура РФ превращается в склоняемое слов по типу наименования Россия: А все эти прихвостни РФии как крысы побегут, если смогут. И не рассказывайте мне бредни про счастливую и развитую Россию... [https://www.donetsk.kp.ru/daily/28304/4444938/].

Отдельного внимания заслуживает топоним, образованный путем сращения украинской указательной частицы и существительного: Вот тогда Украина реально станет Цэевропой [https://www.kp.ru/daily/27257.5/4388731/]. Одним из факторов, способствующих сращению сочетаний слов в единое целое, становится использование подобных выражений в функции хештега.
Фонетическая игра предполагает, что фиксируются какие-то особенности, невозможные в письменной речи. Это может быть ироничная имитация речи носителя украинского, английского языка или иного языка, пародирование московского произношения:

я, вообще, люблю писать Юкрайна. Интересно звучum [https://varlamov/ru/4286078.html].

Полигон укрейна работает бесплатно. Кто-то еще хочет провести какие-нибудь испытания? [https://www. kp.ru/daily/27257/4389540/]

Короче говоря, Уощингтоун и Брюисселе выдвинули хохлам заведомо невыполнимые условия [https://www. kp.ru/daily/27293.5/4431575/].

Фыфрсёррёте !!! На Украине самый большой в мире подводный флот ! У кажном хуторе, селе по нескольку десятков подводных единии и даже у городах, включая Кыив маем их [https://www.kp.ru/daily/28299/4439479/].

да да имеено ее язык, волшбные сказки для свидомых сэлян -дикарей, которыю уже в Еуропе)))) [https://www. kp.ru/daily/27269.5/4403673/]/

Переходим на английский. Украина-цэ Эуропа [https://www.kp.ru/daily/27269.5/4403673/].

Ты то, сиди в своём Изгаиле и не вякай, мерзкий еврей [https://varlamov/ru/2991822.html]. Вся страна на Маaскву скидывается и ничего [https://varlamov/ru/3931856. html].

Фонетическая игра может представлять собой отражение просторечного произношения:

улетела в Ерманию - непорочную политическу девственность сохранять [https://www.kp.ru/ daily/27239.5/4366411/].

Спокойно, ВАЗел. Будет Вам транзит русского мира, через Хранцию [https://www.kp.ru/daily/28303/4443374/].

Орфографическая игра заключается в нарочитом, игровом отступлении от правил орфографии. Акститесь, Товарищи! Телеграфное Агентство Савецкака Саюса ... не станет врать [https://varlamov/ru/4286078. html].

Сёни жыж ачиридной Ваеный Юбилей расии [https:// varlamov/ru/4175614.html]. То скора омерика развалица,.. азирбаджан развалицо,.. укроина развалица,.. Мариуполь сразу будит пагаловно ахвачин ватным референдумом и сразу вайдёт в састав виликой расии [https://varlamov/ru/4172885.html]. 
В интернет-комментариях обыгрывается графический облик слова, написанного на иностранном языке, и особенности транслитерации названия:

Украина - это Россия чи Эвропа? (отсылка к написание слова украинском - Європа) [https://www.kp.ru/ daily/28302.5/4442411/]. Тогда Куев её мочевой пузырь [https://www.kp.ru/daily/27245.5/4373708/]. Последний комментарий отсылает к часто высмеиваемой российскими пользователями истории изменения транслитерации столицы Украины в международных базах: совет США по географическим названиям принял решение о замене официального названия с Kiev на Kyiv.

На лексико-семантическом уровне языковая игра по отношению к топонимам находит свою реализацию, например, в обыгрывании созвучных слов:

Залежалая давно уже протухла с такими «правителями»... )) [https://www.kp.ru/daily/27281.5/4416374/]

Жизнь в Руине! [https://www.kp.ru/daily/27245.5/437 4192/].

Неужели еще кто-то ездит в Нищебродию-Урину? [https://www.kp.ru/daily/28302.5/4442411/]/
Часто в комментариях обыгрывается этимологическая связь слов Украина и окраина: Окраина - это одна из отколовшихся республик бывшего Союза, гдето уровня Узбекистана, Молдавии (с уважением отношусь к этим государствам) ... [https://www.kp.ru/ daily/27266.5/4399943/]. Виртуальная Окраина Совести у виртуального мира вернула Крым. [https://www. crimea.kp.ru/daily/27279/4414731/]. На кой ляд нам эта окраина404?, разберись лучше со своими проблемами внутри страны - большинство народа нищенствуem, еле сводит концы с концами... [https://www.kp.ru/ daily/28302/4443344/]. В последнем комментарии для создания языковой игры используется еще и графический прием: цифры 404 - это символ того, что интернетссылка ведет на несуществующую страницу.

Таким образом, искаженные имена собственные являются результатом словообразовательной, орфографической, графической, фонетической игры. Игровые варианты топонимов, обладающие мощным конфликтогенным потенциалом, становятся средством вербализации провокационных стратегий хейтинга и троллинга, направленных на получение как можно большего отклика аудитории на заданный стимул.

\section{ЛИТЕРАТУРА}

1. Матулевич Т.Г. Формы названий американских штатов как ресурс игрового материала // Язык и культура (Новосибирск). 2013. № 4. С. 65-84.

2. Гридина Т.А. Ментальные ориентиры ономастической игры в малых фольклорных жанрах // Известия Уральского государственного университета. 2001. № 20. C. 234-240.

3. Косиченко Е.Ф. Ономастические игры как основополагающий принцип приключенческого романа // Известия Юго-Западного государственного университета. Серия: Лингвистика и педагогика. 2016. № 3(20). С. 66-72.

4. Ломов А.М., Бабушкин А.П. Имена собственные и языковая игра // Вестник Воронежского государственного университета. Серия: Лингвистика и межкультурная коммуникация. 2013. № 2. С. 158-161.

5. Гридина Т.А., Талмашанов С.С. Языковая игра в современной интернет-коммуникации: метаязыковой аспект // Политическая лингвистика. 2019. № 3(75). C. 31-37.

6. Якунина М.Л. Особенность интернет-дискурса: никнейм // Филологические науки. Вопросы теории и практики. 2013. № 3-2(21). С. $218-221$.

7. убарева А.В. Онимы в интернет-коммуникации: новые явления и функции // Актуальные проблемы филологии и педагогической лингвистики. 2021. №1. C. 120-136.

8. Каллистратидис Е.В. Экспрессивный ономастикон неформальной политической интернет-коммуникации // Культура в фокусе научных парадигм. 2017. № 5. C. 153-160.

9. Шарифуллин Б.Я. Русские речевые игры в интернет-контексте. Этюд 2: ономастика Украины // Человек и язык в коммуникативном пространстве: сборник научных статей. 2016. Т. 7. № 7. С. 63-71.

10. Ким Л.Г. Обыденные политические интернет-комментарии: конфликт интерпретаций новостного текста // Инновационные, информационные и коммуникационные технологии: сборник трудов XVII Международной научно-практической конференции, Сочи, 01-10 октября 2020 года / под. ред. С.У. Увайсов. Москва: Ассоциация выпускников и сотрудников ВВИА имени профессора Н.Е. Жуковского содействия сохранению исторического и научного наследия ВВИА имени профессора Н.Е. Жуковского, 2020. С. 160-164.

11. Плотникова А.М. Языкова игра как средство инвективы // Уральский филологический вестник. Серия: Язык. Система. Личность: Лингвистика креатива. Екатеринбург, 2015. №1. С. 127-133.

(с Фаломкина Ирина Павловна (falomkina@mail.ru). 